\title{
TRUST AND MISTRUST AS STRESS REDUCING AND INCREASING FACTORS IN WORKING LIFE
}

\author{
Jukka Piippo \\ Arcada University of Applied Sciences, Jan-Magnus Janssons plats 1, FI-00550 Helsinki, FINLAND \\ jukka.piippo@arcada.fi
}

Communicated by Andrejs Skaǵers

\begin{abstract}
This paper is a theoretical attempt to investigate possible connections between trust and eustress and also mistrust and distress. The paper includes both empirical material and theoretical material. Empirical material was analysed by using Grounded Theory. According to analysis of both empirical and theoretical material there are connections between the phenomena mentioned. Trust is connected to eustress by several categories, such as mutual process, openness, and leadership of self and versatile interchange of knowing. Mistrust and distress are also connected by several categories: incomprehensibility and embarrassment, indifference, change, and depersonalisation. There were also categories identified as ambivalent categories, since they could be connected to either eustress or distress.
\end{abstract}

Key words: trust, eustress, mistrust, distress, leadership of self, social constructionism.

\section{INTRODUCTION}

Trust is considered as being a basic human need and its development to a high degree depends on interaction within the human environment (Erikson, 1968; Piippo and Aaltonen, 2004; 2008). As a phenomenon it has been studied from several points of view, e.g., Erikson (1968), from a psychological viewpoint, Giddens (1990, 1991), from a sociological viewpoint and Lögstrup (1994), from a philosophical viewpoint. All these viewpoints have similarities, since all consider that trust is a basic human need and that the development of trust depends on interaction with the social environment. Erikson (1968) argues that if the development of basic trust is disturbed, mistrust appears. According to Erikson (1968), if the infant's interaction with his/her social environment is positive, the infant develops an experience of basic trust in him/her self and the environment. In this way, the relation to the mother should not be seen as the only relation that makes the development of basic trust possible. If the early interaction with the environment does not develop well, the infant can experience mistrust in the environment and this can lead to isolation and anxiety. However, Erikson does not see the first phases in the infants' development as definitive. A person's later development, if it progresses favourably, can compensate for earlier crises and the person can experience basic trust. Lögstrup (1994) agrees with Eriksson. According to Lögstrup, an infant entertains trust without reservation. When an infant expresses trust he/she opens up him/herself and becomes vulnerable. If the infant is not met with love, trust is turned into distrust because if trust is met by some other attitude than trust, it creates mistrust. Luhmann (1979) considers trust not to be based in an individual's actions but as actions of communicative actors. He argues that communication is fundamental for the creation of trust. According to Erikson (1968) and Giddens (1991), even experience and development of safety depends on the persons' basic trust: trust and safety are interdependent. Giddens $(1990,1991)$ argued that the development of trust is a mutual process between two or more persons, a process which includes disclosure and honesty. When one side discloses something personal about him or herself, he/she invites the other side to also disclose something personal. This kind of process continues, according to Giddens (1990, 1991), and becomes stronger when the trust developed is not betrayed. In such a process, honesty is important, since all participants are vulnerable and if the disclosed personal issues are misused, the process stagnates.

Trust is also an important factor within working communities and other situations of human interaction. Concerning trust within working communities, three significant factors can increase experience of trust: participating and justified leadership, functional working-group and increasing of workers independency (Gilson, 2003). The phenomenon of trust has also been studied from the social capital point of view (Jokivuori, 2005; Sinervo, Elovainio et al., 2005) as well as outside working life (Helkama and Seppälä, 2004; Piippo and Aaltonen, 2008). Based on these studies, we can assume that trust as an independent phenomenon is difficult to study about, since its development is connected and influenced by several factors. 
Stress can be considered as having both negative (distress) and positive (eustress) sides and effects (Selye, 1974). Distress, identified as having negative implications, is the most common type of stress. Eustress is the positive cognitive response to stress, which can be considered as healthy or giving one a feeling of fulfilment and other positive feelings (Selye, 1974). When it is a question of occupational stress, eustress may be measured on subjective levels such as of quality of life or working life, job pressure, psychological coping resources, complaints, overall stress level, mental health and challenges connected to work. According to McGovan et al. (2006) there is no single definition of stress, but authors also conclude that occupational stress is caused often by experiences in the working environment. Research on eustress has focused on its presence in the workplace, where stress can often be interpreted as a challenge, signifying positive eustress. Stress can also be seen as a hindrance, which refers to distress that interferes with one's ability to carry out a job or assignment. Negative stress should generally be reduced and sometimes positive stress might increase wellbeing in working life. Also according to Lazarus $(1966,1991)$ eustress can be regarded as positive and cognitive response to stress that is healthy. It can give a person experience of succeeding or other positive feelings, and it depends on how one understands or receives a stressor. Eustress is correlated also mostly positively with life satisfaction and well-being. The concept of eustress was originally introduced by Selye (1974) as the entirety of positive adaptive reactions. It is the opposite of distress, which, according to Selye, can be regarded as a specific syndrome that is triggered by unspecific harmful stimuli or activities. For Selye, eustress represents pleasant stress without harmful consequences of damaging distress. Selye also regards stressors as being healthy when they do not disturb a person's experience of homeostasis or balance in life.

As well as Selye, even Lazarus (1966) considers that challenges function as stressors and that challenges can manifest themselves under different kinds of circumstances. When a goal for work or action is experienced as relevant and goal congruence is understood, the person's involvement increases positively not only self-esteem, but also social esteem, and aspects of the environment and a person's internal and external conditions are suitable. According to Selye's (1983) later research, which have seen as being influenced by the work of Lazarus, eustress and/or distressful quality of a stressor depends on the person's interpretation of the context.

Connections between stress, as well eustress as distress, and development of trust and mistrust have not been identified, even if these phenomena occasionally are related to each other. This prompted us to conduct this theoretical study of the connections between these phenomena.

The aim of the study was to find connections between (1) eustress and trust and (2) distress and mistrust, and to determine how these phenomena can be connected to each other, by relating results from empirical studies concerning trust/mistrust to theoretical aspects of eustress/distress.

\section{MATERIALS AND METHODS}

Material for this study consists of earlier research concerning development of trust and theoretical literature-based material concerning eustress and distress. Material for research concerning development of trust consisted of: (1) interviews with 22 patients under Mental Health Care; (2) interviews with their family members and members of the treatment team responsible for the treatment; (3) interviews with 47 social- and healthcare and information and communications technologies (ICT) workers in individual or group interviews (Piippo and Aaltonen 2004; 2008; 2009). Literature consisted of articles and internet sources concerning eustress and distress.

Patients interviewed (first study) were recruited verbally among adult persons who had contact with social services and mental health services in the city of Västerås, Sweden. All informants had also been participating in a development project in the area (Piippo and Aaltonen, 2004; 2008). All informants gave their verbal consent. The interviewed patient group consisted of six men and sixteen women aged between 20 and 60 years. The study was approved by the Ethical Committee at Uppsala University, Sweden.

Persons participating in the second study were recruited by staff in the outpatient clinic at Jorvi Hospital, in the city of Espoo, in southern Finland and in the outpatient clinic at Keropudas Hospital, in the psychiatric catchment area of Western Lapland (Piippo and Aaltonen, 2009). The patients had been in family-oriented treatment for at least two years, and their family members were expected to participate actively in the treatment process. All participants gave their written consent. The group consisted of five women and five men with their family members and two or three members of the responsible treatment team. The study was approved by the Ethical Committee of Western Lapland.

Persons participating in the third study were recruited among personal from organizations participating in the OSUVA-project (http://www.osuva-foorumi.fi) and WASIproject (http://info.arcada.fi/sv/wasi/project-overview) realized in Finland. All informants gave their written consent, and participation was voluntary. The group consisted of about $50 \%$ women and $50 \%$ men. Both studies were approved by either an ethical committee or responsible person in the organisation. These interviews started with one simple question: What happened when you came to this clinic at the first time?

The method used for analysing the interviews was application of Grounded Theory. Grounded Theory and its application have been developed during several decades (Glaser and Strauss, 1967; Strauss, 1987; Corbin and Strauss, 1990; Glaser, 1992; Pandit, 1996; Strauss and Corbin, 1998). According to Strauss and Corbin (1998), Grounded Theory provides the researcher with tools to deal with amounts of material and helps the researcher to notice the various 
meanings of a phenomenon. According to Glaser and Strauss (1967), Grounded Theory is suitable for research areas where there has been little recent theory development, since only little information on relevant theory development was found in the literature while carrying out this research.

The process of applying Grounded Theory is described differently by different researchers. According to Tesch (1990), the main interest in Grounded Theory is to seek regularities, to identify and categorise elements, and to study the relations between them. Chenitz and Swanson (1986) consider Grounded Theory to be especially suitable and important for research areas in which there is need for new points of view. The main principles of Grounded Theory are open coding, axial coding, selective coding and continuous comparison between codes, memos and categories. Open coding incorporates free analysis mostly of written material, for example transcripts of interviews. During this process, the researcher identifies utterances which are interpreted to mean something. When this process continues, it is possible and indeed unavoidable that different utterances can be gathered into the same category because they have the same or similar meaning. Axial coding involves comparison between the categories and analysis of how they are related to each other. If and when connections are found, it becomes possible for the researcher to identify the core category (selective coding) among the categories initially identified. Selective coding is the process of choosing one category to be the core category, and relating all other categories to that category. During the whole process of analysis, continuous comparison is carried out. The core category of the analysis was trust.

The methods used in the analysis are described in Esaiasson et al. (2003). The goal of this research method is to explore similarities, differences and connections between the research objects. In this study, investigation was made between results from earlier research and theoretical material to identify similarities that could be regarded as connecting trust with eustress and mistrust with distress.

\section{RESULTS}

Categories increasing and developing trust, which are connected to eustress. During the analysis of the empirical material collected in previous research (Piippo, 2004; 2008; 2009), categories increasing and developing trust were identified. Six of those identified categories - mutual process, responsibility, openness, autonomy, leadership of self and versatile interchange of knowing - are categories of increased trust and can be considered as being connected to eustress (Fig. 1). These categories are also connected to each other and depend on each other, since none of them can be seen as increasing trust alone. According to the theoretical comparison, these categories include challenge, interaction, and responsibility, which are closely connected to eustress (Lazarus, 1966; Selye, 1974). Especially challenge is seen as an important factor for eustress by Selye (1974) and Lazarus (1966). When it is the question of creating a mutual process with colleagues at working places, this can be regarded as making a challenge to the employers and also people in general. Mutual process itself can also be seen as challenging, since being in a mutual process with others requires openness, leadership of self in interactions with others, responsibility and also capability to interchange knowing from all parts participating in the process (the word knowing is used, since in this context it is not a question of knowledge of facts but more about social knowing, e.g. Piippo, 2008). One of persons interviewed stated: "In the meetings I participate in, I have experienced mutual communication. I often feel relieved afterwards, I feel that things have been clarified, I can cope with things." Another person stated: "I think that trust develops from small experiences in working-life... for example between employee and employer when the employer supports me... the employer can support some small issue and understand how important it is for the employee."

In this kind of process it is also important for persons to retain their autonomy even if they are part of a larger collective. If we regard leadership of self, interaction, and responsibility as being factors connected to eustress, it is obvious that trust and eustress are connected to each other. A very important form of challenge to each person is challenging

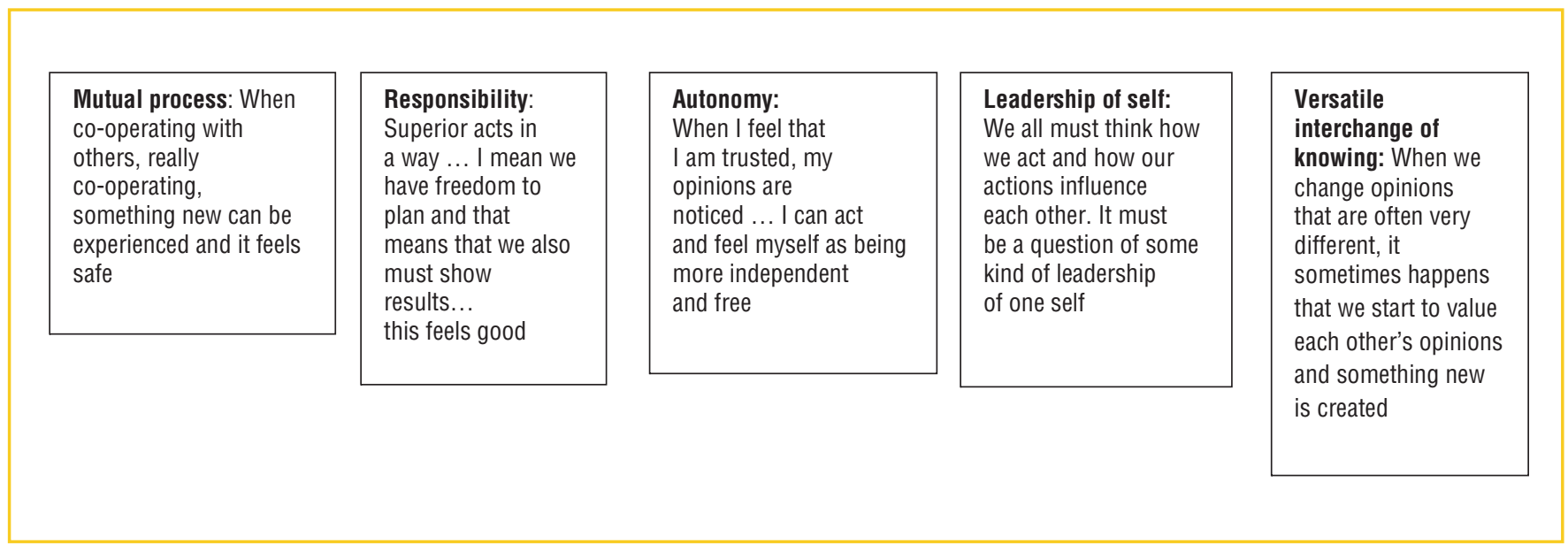

Fig. 1. Categories of trust with quotations. 
him/her self and his/her inner thoughts in relation to others. Challenging oneself can be seen as challenging their own ideas and thoughts, which can also be regarded as being social constructions (Berger and Luckman, 1966). Social constructions in turn can be seen as beliefs or inner descriptions of truth, which have a specific kind of background and are created according to one's inner life. In working life including social interaction with others, ones inner life and thoughts can often become challenged by others, which can lead to a stressful situation to a person. If a person in such circumstances has the cognitive capacity (secondary appraisal) to meet that kind of challenge (primary appraisal), we can assume that the person experiences meaningfulness, hope and positive affects, which are connected to eustress (Lazarus, 1966). Meaningfulness and hope are also aspects which are connected to development of trust (Piippo and Aaltonen, 2004; 2008). The main focus on the process of primary and secondary appraisal is on the individual and the situational aspects that interact in the appraisal of a stressor to produce an outcome (McGowan et al., 2006; Sulsky and Smith, 2005). Especially in working life this kind of process can also be seen as including versatile interchange of knowing between personnel at different levels.

Categories decreasing trust and increasing distress. Analysis of the empirical material resulted in identification of categories decreasing trust: incomprehensibility and embarrassment, indifference, change, depersonalisation (Piippo, 2008; 2009; 2013) (Fig. 2). These categories differed from those connected to development of trust, since the categories can lead to mistrust as single categories, and they do not necessarily connect to each other. According to Selye (1975), distress includes and can lead to anxiety, uncertainty, and withdrawal. The categories identified as leading to mistrust can, according to the theoretical analysis, be connected to distress, since also they all include the same phenomena. It can be regarded as obvious and novel that when a person, in an occupational or other situation, experiences incomprehensibility and embarrassment, leading to experience of anxiety and uncertainty and then also to experience of distress. According to analysis of the interviews, especially changes at working places were most often experienced as creating distress. Personnel experienced uncertainty about their employment, and/or replacement at work, which they were not very familiar with. Also, a change of leader was experienced as causing anxiety and uncertainty, since personnel were not familiar with the new leader and his/her way of functioning. When people experienced uncertainty, they also experienced mistrust; in fact, mistrust can be seen as manifesting itself before experience of uncertainty (Piippo, 2009).

Ambivalent categories. There were also some categories that could not be seen as leading to either eustress or distress: turnover rate, model for working, inequality-undemocratic. All these categories were identified from interviews with personnel working either in social- and healthcare or ICT workers. These categories are not connected to each other, and surprisingly, it seems that they can lead either to eustress or distress, probably depending on an individual's capacity to meet this kind of stressor. It seems also quite obvious that these categories include challenge, changes, and also curiosity, but the way a person receives the stressor has influence on whether it is experienced as eustress or distress. Concerning the turnover rate, persons interviewed mostly experienced as problematic, since turnover rate concerned their nearest superior. However, some of the persons interviewed experienced it as positive change and a kind of a challenge, and beginning of something new. Some were also curious about the future. A model for working was in some cases connected to the category inequality-undemocratic, since some personnel from the working group might benefit from this by favourable treatment. Also, concerning this category, the individual's way of receiving the stressor affected whether it was experienced as eustress or distress.

\section{DISCUSSION}

This study was theoretical, but also included empirical research. Analysis of categories increasing and developing either trust or mistrust seemed to provide similar results, independent of who the persons interviewed were: clients at mental health care, family members, or personnel working either in social and health care, or ICT workers. Development of trust is not connected to diagnosis, but more to circumstances in the environment and also possibilities for a person to function and interact with others. However, development of basic trust, which is considered as being dependent on the social environment in the early ages of a person's life, is of importance for development of trust. It can also be seen as being of significant for experience of eustress or distress. According to the analysis, positive response to stressor can depend on one's feelings of having control, desirability, and basic trust. When a person experiences strong

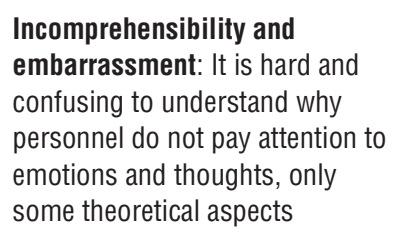

Indifference: Why I

should feel myself a bit like an outsider? I am not equal with others, since certain persons become invited to development, they are trusted
Change: During the process I have been thinking how I should relate to things that are going on... can I trust the future
Depersonalisation: My life has been understood according to general theories... not according to who I am and my life situation

Fig. 2. Categories of mistrust with quotations. 
basic trust, a person has also cognitive capacity to meet stressors, challenges, and difficult situations without experiencing them as demands or risks.

Many studies have shown that, depending on how a person experiences stressors, the stressor, either demand or a challenge, leads to eustress or distress (Lazarus, 1991; Selye, 1974; Le Fevre, Matheny and Kolt, 2003). The individual's interpretation of stressors can be looked in the light of social constructionism (Berger and Luckmann, 1966). According to social constructionism there is no real truth and no only right way to understand phenomena and things happened. According to Berger and Luckmann (1966), the social construction of reality can be understood as a person's way of understanding reality, which also can be seen as stressors a person meets. Stressors are a part of human beings reality, since we always are meeting different kind of stressors. Selye (1974) and Lazarus (1966) argue that a person's cognitive capacity, including a person's skills to handle with information, memory, attention, problem solving and learning skills, of receiving a stressor is important. In occupational life, interaction with others happens all the time and this also creates different kinds of stressors that persons must interpret to meaning something. Shotter's (1997) considers that the nature of social constructionism is about spontaneously occurring dialogical activities between people. Shotter's idea is in line with the views of Berger and Luckmann (1966) and Gergen (1985), although social activities are something people are part of also in working life and it can be regarded as having great importance to how we experience stress. According to Gergen and Gergen (1988), cultural, historical and social contexts form the basis for how things are interpreted and also for knowledge and understanding. Individuals live in their occupational cultures and are surrounded by the traditions of those cultures, and these influence how individual's value understanding, and these factors influence also a person's way of interpreting stressors (Giddens, 1991). It is a question of how different individuals" "being-in-the-world", including their lived experiences, history, culture and societies, interact with each other in working life. Also Linell (1998) considered social constructions to be not only based on verbal activities, but also to have a socio-cultural dimension. Meeting a stressor and interpreting it is something that happens in a person's inner life and in this way it can be seen as being a social construction, understanding and personal interpretation of a stressor.

"Leadership of self" and its significance to development of trust and experience of eustress vs. distress can be discussed, since it is connected to the idea of social constructionism and includes a person's inner life, which gives a person possibilities to experience trust and also interpret stressors (Sydänmaalakka, 2004; 2006). Heikkala (2009) defines leadership-of-self as a person's inner activity, which includes reflective considering and belief of one's self. Furthermore, according to Piippo (2013), leadership of self is connected to a person's capability to view him/herself as from outside, distance him/herself from self so the person obtains possibilities to experience him/herself and his/her importance to the human environment. In other words, this means viewing one's own otherness, which can also be understood in light of social constructionism (e.g., Linell, 1998). In this case social construction is not only a mental image but a more deep issue including inner reflective view of self. Leadership of self is also connected to basic trust, since basic trust can be seen as a prerequisite to leadership of self. A low basic trust, which can also be regarded as a hidden basic trust, is a hindrance for a person in functioning and probably also influences a person in interpreting things and stressors. It can be assumed that low basic trust influences a person's interpretations of stressors in a negative way and then stressors are experienced as demands, which leads to experience of distress. Assumption that low basic trust can be understood as hidden basic trust is based on research showing that trust can be strengthened in suitable circumstances where a person experiences acceptance and autonomy and where mutual understanding is possible to create (Piippo and Aaltonen, 2008; 2009).

It can also be thought that the form of authority is connected to development of trust and experience of eustress vs. distress. According to Gadamer (2003), there are two kinds of authorities and also two kinds of power. Firstly, an authoritarian authority who wants to regard him/her-self as authority and in a way wants to own the power, especially when it is about knowledge and knowing. That kind of authority can be connected to vertical expertise, an expertise in which somebody knows more and better than others. Secondly, an authoritative authority for whom the power is not an issue, but a phenomenon that could and should be shared. Since all relations are mutual but in different ways, Gadamer (2003) argues that an authoritarian authority has no authority from other participants' point of view. According to Gadamer, it can assumed that a leader who has authoritarian authority can create situations at working places that are experienced as distress. This is because that kind of authority does not act in a way leading to mutual processes, openness and versatile interchange of knowing. In contrast is authoritative authority by a process-oriented leader who needs other personnel's ideas and thoughts for creating a good working place. This kind of leadership can be regarded as creating more situations in which personnel experience challenges leading to eustress. Also Maciocha et al. (2012) conclude that shared knowledge and joint creativity are related to experience of positive stress and are connected to leadership and the leader's attitude. This is in line with Näsman (2011), who considered that organizations with poor leadership and communication create feelings of stress (distress) and anxiety. Leadership can contribute to good communication and thereby increase experience of eustress and cooperation (Maciocha et al., 2012)

Need for further research. This article is theoretical and cannot give definite explanations for connections between especially trust and eustress. Therefore, there is need for further research on how this topic, to create better working 
environments, especially human environments, at working places and organisations.

\section{REFERENCES}

Berger, P. L., Luckmann, T. (1966). The Social Construction of Reality. Doubleday, New York. 125 pp.

Chenitz, W., Swanson, J. (1986). Qualitative research using grounded theory. In: Chenitz W., Swanson, J. (eds.). From practice to grounded theory. Addison-Wesley, Menlo Park, pp. 3-15.

Corbin, J., Strauss, A. L. (1990). Grounded theory research: Procedures, canons and evaluative criteria. Qualit. Sociol., 13, 3-21.

Erikson, E. H. (1968). Identity: Youth and Crisis. Norton, New York. 336 pp.

Esaiasson, P., Oscarsson, H., Wängnerud, L. (2003). Methodpractice. The art of studying society, individual and market. Norstedts Förlag, Stockholm (in Finnish). 462 pp.

Gadamer, H.-G. (2003). The Mysterious Health. Dualis Förlag AB, Ludvika (in Finnish).

Gergen, K. (1985). The social constructionist movement in modern psychology. Amer. Psychologist, 40, 266-275.

Gergen, K. J., Gergen, M. M. (1988). Narrative and the self as relations. Advances in experimental social psychology, 21, 17-56.

Giddens, A. (1990). The Consequences of Modernity. Standford University Press, London. 188 pp.

Giddens, A. (1991). Modernity and Self-identity. Self and Society in the Late Modern Age. Polity Press, Cambridge. 264 pp.

Gilson, L. (2003). Trust and the development of health care as a social institution. Soc. Sci. Med., 56 (7), 1453-1468.

Glaser, B. G., Strauss, A. L. (1967). The Discovery of Grounded Theory. Strategies for qualitative research. Aldine De Gruyter, New York. 284 pp.

Glaser, B. G. (1992). Basics of Grounded Theory Analysis. Sociology Press, Mill Valley. 128 pp.

Heikkala, J. (2009). Manual of Wellbeing at work organisations. Suomen Liikunta ja Urheilu, Helsinki. 27 pp. (in Finnish).

Helkama, K., Seppälä, T. (2004). Change of values in Finland from 1980 to 2000. Available at: www. sitra.fi /julkaisut (in Finnish).

Jokivuori, P. (2005). Fields of Social Capital. Minerva kustannus, Jyväskylä (in Finnish).

Lazarus, R. S. (1966). Psychological Stress and the Coping Process. McGraw-Hill Book Co, New York, Toronto, London. 466 pp.

Lazarus, R. S. (1991). Psychological stress in the workplace. J. Soc. Behav. Pers., 6 (7), 15-20.

Le Fevre, M., Matheny, J., Kolt, G. S. (2003). Eustress, distress, and interpretation in occupational stress. J. Manag. Psychol., 18 (7), 726-744.

Linell, P. (1998). Approaching Dialogue. Talk, Interaction and Contexts in Dialogical Perspectives. John Benjamins Publishing, Amsterdam. 330 pp.

Luhmann, N. (1979). Trust and Power. John Wiley, New York. 228 pp.
Lögstrup, K. E. (1994). The Ethical Demand. Mediaprint AB. Uddevalla (in Finnish).

Maciocha, A., Surakka, J., Näsman, O. (2012). Work ability and social inclusion project: enhancing collective knowledge through leadership and stress management. In: Congress Proceedings. $4^{\text {th }}$ European Congress of Intellectual Capital, Finland 23-24 April. Arcada Library, Helsinki.

McGowan, J., Gardner, D., Fletcher, R. (2006). Positive and negative affective outcome of occupational stress. New Zeal. J. Psychol., 35 (2), 92-98.

Näsman, O. (2011). Metal Age and Kiva-questionnaire. Mediona/The Archipelago Academy for Well-being at Work. Finland. 35 pp.

Pandit, N. R. (1996). The creation of theory: A recent application of the grounded theory method. The Qualitative Report 2. Available at: http://www.nova.edu/ssss/QR/QR2-4/pandit.htlm (accessed 12 September 2012).

Piippo, J., Aaltonen, J. (2004). Mental health: Integrated network and family-oriented model for co-operation between mental health patients, adult mental health services and social services. J. Clin. Nurs., 13, 876-885.

Piippo, J., Aaltonen, J. (2008). Mental health care: Trust and mistrust in different caring contexts. J. Clin. Nurs., 17 (21), 2867-2874.

Piippo, J., Aaltonen, J. (2009). Mental health and creating safety: The participation of relatives in psychiatric treatment and its significance. J. Clin. Nurs., 18 (14), 2003-2012.

Piippo, J. (2013). Luottamus psykiatrisessa organisaatiossa ja sen eri tasoilla [Trust within Psychiatric organization on different levels]. Perheterapia, 2 (13), 20-26 (in Finnish).

Selye, H (1974). Stress Without Distress. J.B. Lippincott Company, Philadelphia. $171 \mathrm{pp}$.

Selye, H. (1975). Confusion and controversy in the stress field. J. Human Stress, 1, 37-44.

Selye, H. (1983). The stress concept: Past, presence and future. In: Cooper, C. L. (Ed.). Stress Research: Issues for Eighties. John Wiley, New York, 1-20. Shotter, J. (1997). The social construction of our "inner" lives. J. Constr. Psychol., 10, 7-24.

Sinervo, T., Elovainio, M., Pekkarinen, L., Heponiemi, T. (2005). Equitability of an organization as basis for trust and motivation. In: Jokivuori, P. (Ed.). Sosiaalisen pääoman kentät [Fields of Social Capital]. Minerva kustannusosakeyhtiö, Jyväskylä, pp. 133-146 (in Finnish).

Strauss, A. (1987). Qualitative Analysis for Social Scientists. New York: Cambridge University Press. 336 pp.

Strauss, A., Corbin, J. (1998). Basic of Qualitative Research. Techniques and Procedures for Developing Grounded Theory. $2^{\text {nd }}$ ed. Sage Publications, Thousand Oaks. 456 pp.

Sulsky, L., Smith, C. A. (2005). Work Stress. Thomson Wadsworth. Belmont, CA, USA. 338 pp.

Sydänmaanlakka, P. (2004). Intelligent Leadership. Helsinki. Talentum (in Finnish). $256 \mathrm{pp}$.

Sydänmaanlakka, P. (2006). Intelligent Leadership of Self-perspectives to Personal Growth. Gummerus, Jyväskylä (in Finnish). 323 pp.

Tesch, R. (1990). Qualitative Research: Analysis types and software tools. Falmer Press, New York. 330 pp.

Received 11 September 2014

\section{UZTICĒŠANĀS UN NEUZTICĪBA KĀ STRESA MAZINĀŠANAS UN PALIELINĀŠANAS FAKTORI DARBA DZĪVĒ}

Raksts ir teorētisks mēǵinājums izpētìt iespējamo saikni starp uzticēšanos un "labo stresu", neuzticību un ciešanām. Rakstā ietverts gan empīirisks materiāls, gan teorētisks materiāls, kas parāda saistību starp minētajām parādībām. Uzticēšanās ir saistīta ar "labo stresu" vairākos veidos, piemēram: savstarpējas attiecības, atvērtība, paškontrole un zināšanu daudzpusīga apmaiņa. Neuzticēšanās un diskomforts apvienoti vairākās kategorijās: nesaprotamība un apmulsums, vienaldzība, personības izmainas un depersonalizācija. Tika arī identificētas vairākas kategorijas, kas varētu būt saistītas ar "labo stresu" vai ciešanām. 